\title{
Improving ecosystem service frameworks to address wicked problems
}

\author{
$\underline{\text { Kathryn K. Davies }}^{1}, \underline{\text { Karen T. Fisher }}^{2}$, Mark E. Dickson $^{2}, \underline{\text { Simon F. Thrush }}^{2,3}$ and $^{\text {Richard Le Heron }}{ }^{2}$
}

\begin{abstract}
Complex problems often result from the multiple interactions between human activities and ecosystems. The interconnected nature of ecological and social systems should be considered if these "wicked problems" are to be addressed. Ecosystem service approaches provide an opportunity to link ecosystem function with social values, but in practice the essential role that social dynamics play in the delivery of outcomes remains largely unexplored. Social factors such as management regimes, power relationships, skills, and values, can dramatically affect the definition and delivery of ecosystem services. Input from a diverse group of stakeholders improves the capacity of ecosystem service approaches to address wicked problems by acknowledging diverse sets of values and accounting for conflicting world views. Participatory modeling can incorporate both social and ecological dynamics into decision making that involves stakeholders, but is itself a complex social undertaking that may not yield precise or predictable outcomes. We explore the efficacy of different types of participatory modeling in relation to the integration of social values into ecosystem services frameworks and the generation of four important elements of social capital needed to address wicked problems: enhancing social learning and capacity building; increasing transparency; mediating power; and building trust. Our findings indicate that mediated modeling, group mapping, and mental/conceptual modeling are likely to generate elements of social capital that can improve ecosystem service frameworks. Participatory simulation, system dynamic modeling, and Bayesian belief networks, if utilized in isolation, were found to have a low likelihood of generating the social capital needed to improve ecosystem services frameworks. Scenario planning, companion modeling, group model building, and participatory mapping all generate a moderate to high level of social capital elements that improve the capacity of ecosystem service frameworks to address wicked problems.
\end{abstract}

Key Words: ecosystem services; participatory modeling; social capital; social values; wicked problems

\section{INTRODUCTION}

In the 21 st century it is increasingly clear that human activities can impact ecosystems at every scale and that wicked problems often result from these interactions. Wicked problems are characterized by complexity, uncertainty, interdependence, and dispute, and tend to be found in highly interconnected socialecological systems. Problems associated with climate change, genetically modified foods, and aquaculture can all be classified as wicked. Conventional command and control approaches typically fail to achieve positive management outcomes when faced with wicked problems (Berkes et al. 2003); consequently, new approaches to decision making are needed. Explicit consideration of the interactional nature of ecological and social processes is required to improve upon conventional decision making structures (Brown et al. 2010). In this regard, ecosystem services (ES) approaches have emerged as a link between underpinning ecosystem functions and social values. International environmental science and policy institutions have embraced ES approaches (Daniel et al. 2012), but the literature is surprisingly silent on the critical role that social dynamics play in enabling ES frameworks to generate improved social-ecological outcomes. Participatory modeling (PM) is often used to derive social-ecological outcomes because it involves the use of modeling in support of a decision-making process that includes stakeholders. We address the potential of different PM methods for improving ES frameworks by integrating social values and generating elements of social capital, a term commonly used to describe relations of trust and reciprocity, that will aid in addressing wicked problems.

ES are defined as the benefits that people obtain from ecosystems and are usually grouped into provisioning services (e.g., food), regulating services (e.g., flood control,) cultural services (e.g., recreation), and supporting services (e.g., nutrient cycling; Millennium Ecosystem Assessment 2003). Although there are challenges associated with the process of quantifying ecosystem functions and measuring the services resulting from these functions, ES frameworks can enable the explicit examination of trade-offs in service provision, minimizing surprise shifts in the provision of ES and aiding in the process of identifying who benefits and who loses under alternative management scenarios (Granek et al. 2010). This use of ES as a communication tool adds new dimensions to its utility over a purely economic or functional approach to the valuation of nature. However, current ES approaches do not satisfactorily account for social or ecological factors, or the interactions between them (Reyers et al. 2013). Elements such as management regimes, power relationships, skills, and values, can dramatically affect the definition and delivery of ES, because ultimately services must support individual or societal values. More generally, facilitating the inclusion of diverse knowledge and value sets from academic disciplines, management practices, and public domains also remains a critical challenge for ES approaches (Cook and Spray 2012, Cote and Nightingale 2012) because of the relative influence and privilege associated with each set (Raymond et al. 2010).

It is generally agreed that input from a diverse group of stakeholders is needed to effectively represent social values in environmental decision-making processes (Beierle and Cayford 2002, Irvin and Stansbury 2004, Reed 2008). Diverse stakeholder participation in ES approaches is crucial for several reasons: first, stakeholder participation can contribute knowledge at a range of scales, which is needed to support adaptive governance and ecosystem-based management programs (Gadgil et al. 2003); 
second, stakeholder engagement can lead to higher quality and more durable environmental decision making (Millennium Ecosystem Assessment 2005); and third, early and ongoing stakeholder input can improve the efficiency of implementation processes, saving time and money on litigation and political wrangling (Pahl-Wostl and Hare 2004).

Despite the relative consensus that participation in environmental decision making is needed, all types of participation are not necessarily equal. The definition of "participation" is highly variable (e.g., Arnstein 1969, Nelkin and Pollak 1979, Weidemann and Femers 1993), and can refer to the public's passive reception of information generated by decision-making bodies; token forms of consultation such as systems of check-box approval; the collection of public opinion and input through questionnaires, interviews, or focus groups; and the participation of representatives in decision-making processes such as advisory committees (Rowe and Frewer 2000). Regulatory frameworks increasingly require participatory components, but important questions remain regarding the kind of stakeholder input elicited and the ways in which participation is undertaken. Not surprisingly, different forms of participation can produce a variety of results and conclusions regarding their effectiveness in accessing and incorporating societal values into management processes. Selection of participatory tools matters (Lynam et al. 2007): although appropriate tools do not guarantee success, inappropriate tools are likely to detract from it. Prior to choosing appropriate participatory methods for a project, it is important to consider the project objectives, the level of stakeholder engagement required, and to identify relevant stakeholders to include; however, the level of stakeholder engagement is likely to be the primary determining factor when assigning methods (Reed 2008). An advance awareness of the methodological strengths and weaknesses of different approaches can aid interpretation of results (Lynam et al. 2007).

Different types of participation may be appropriate for different circumstances, contexts, and goals, but where wicked problems are concerned, it is likely that participatory processes incorporating technical information, education, and analysis will facilitate more effective long-term resolutions than processes involving cursory forms of participation such as traditional public hearings (Pahl-Wostl and Hare 2004). Certain kinds of participation can also develop critically needed social capital; in addition to relations of trust and reciprocity, this may include the establishment of common rules and norms, and the connectedness of institutions and social networks (Pretty and Ward 2001, Folke et al. 2005). Social capital has been linked to the generation of adaptive governance and management, is often considered to be a critical element that enables collaboration and collective action (Adger 1997, 2003, Berkes and Seixas 2005, Lebel et al. 2006), and is associated with the capacity to resolve wicked problems (Morris et al. 2013). However, social capital does not simply emerge from any type of social interaction. The generation of important elements of social capital such as social learning requires the convergence of appropriate political, institutional, and social contexts, as well as the deployment of particular participatory processes (Tippett et al. 2005).

A clearly defined process of negotiation and communication about what is valuable and appropriate data, information, and knowledge is an essential aspect of any decision making that involves models (Van Wyk et al. 2008). PM is hailed as one of only a few mechanisms that can both facilitate social learning and encourage the multidirectional exchange of information that can impact outcomes (Stringer et al. 2006). PM approaches have also been touted for their ability to incorporate both social and ecological dynamics (Voinov and Bousquet 2010). Additional benefits attributed to PM methods include increasing social capacity, enhancing cross sector collaboration, improving the adaptability of governance and management regimes, identifying the social value of ES, and highlighting the trade-offs associated with alternative scenarios. PM approaches can also provide a heuristic device that enables the development of a common understanding of complex problems (Haag and Kaupenjohann 2001), and a PM model or set of models may enable scenario testing in a virtual world (Prell et al. 2007).

The diversity of the people involved in PM is one of the approach's most important strengths but also one of its primary weaknesses because the variety of power relationships (Reed 2008), opinions, values, emotions, and capacities to process information can be difficult to manage (Prell et al. 2007). PM can also be time consuming and outcomes are not always imminent, which places participatory projects at risk of losing the engagement of participants, managers, or policy makers charged with effecting change (Prell et al. 2007). PM is itself a complex, contingent social process that interacts with institutional structures, knowledge frameworks, and power relationships at different scales. As such, PM can yield unexpected outcomes, and should not be considered a tool that can be applied with precision and predictability. Other PM challenges include accounting for the informal processes that contribute to knowledge generation and the networks that support governance and management (Cook and Spray 2012), and the verification and validation of participatory models (Millington et al. 2011).

We view PM as a way to facilitate outcomes that increase the common good, including but not limited to articulating and improving understanding. We believe that PM is well positioned to improve the capacity of ES frameworks to address wicked problems because of its dual purpose as (1) a method that can integrate social values into decision making frameworks, and (2) a process that can reduce uncertainty and risk by developing particular elements of social capital. This social capacity to cope with change is required for building resilience in social-ecological systems (Folke et al. 2003). PM can generate or enhance qualities that improve the ability of ES frameworks to address wicked problems, but different qualities are emphasized by different PM methods. We explore the capacity of a variety of PM methods to integrate social values into ES frameworks, as well as the proficiency of these methods to develop several important elements of social capital: social learning and social capacity (Pahl-Wostl and Hare 2004, Krueger et al. 2012); transparency (Korfmacher 2001, Granek et al. 2010); the mediation of power (Stringer et al. 2006); and trust (Lebel et al. 2006). The assessment that follows highlights the role for and importance of the social sciences in improving environmental outcomes when problems are wicked.

\section{METHODS}

We examine to what extent and under what conditions a range of PM methods, in conjunction with ES approaches, can address wicked problems in highly contested coastal environments. To do 
this, we surveyed, analyzed, and evaluated selected PM methods that have been utilized in natural resource management and research, where possible in connection with coastal systems and/ or ecosystem services. Similar to the review of participatory tools conducted by Lynam et al. (2007), our process included an extensive literature review and the establishment of a framework for analysis, which involved identifying a set of criteria for evaluating each PM method. Three iterative rounds of discoursebased valuation (Wilson and Howarth 2002) were undertaken to reach consensus regarding appropriate scores for the PM methods and associated social qualities. The first round involved identifying a set of probable PM examples and ensuring their aims and procedures were sufficiently different to be considered, the second round established the particular social qualities needed to contribute to resolving wicked problems, and the third round involved assigning rough criteria and debating appropriate scores. The scores provided in this study are based on our extensive experience as biophysical and social scientists who have engaged stakeholders in modeling exercises in complex coastal environments.

Fig. 1. Participatory modeling (PM) types were scored on a scale of $0-1(0=$ Low, $1=$ High $)$, ranked by the average (assuming no weighting), and organized from highest total score (top) to lowest total score (bottom). PM types at the top of the figure are likely to contribute more to the development of ecosystem services (ES) frameworks that can address wicked problems than those located toward the bottom.

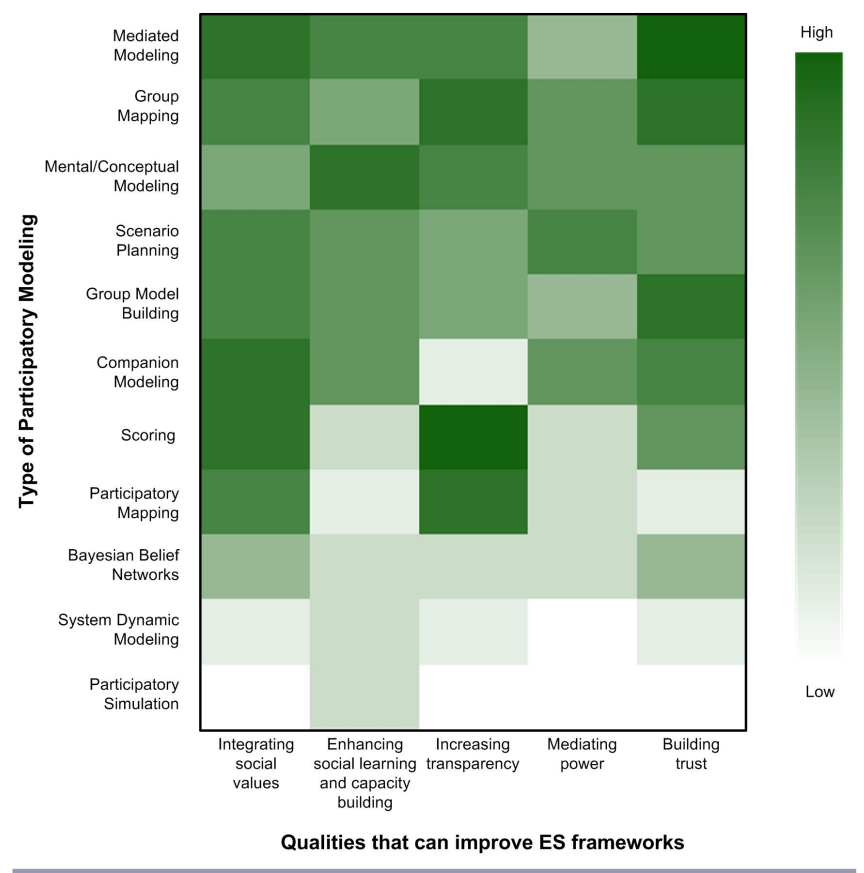

We did not consider expert-driven predictive mathematical models in our review, although there is potential to effectively use such approaches within a PM framework. Nevertheless, a wide range of expertise requirements were considered that provided clear pathways for stakeholder input. PM approaches encompassed in our analysis ranged from those that require the participation of an experienced modeler to those that allow a diverse group of participants to contribute to the process of model building with little guidance. The mapping literature generally refers to all methods resulting in a collective spatial representation as "participatory mapping." However, in Table 1 and Figure 1, we include two distinct mapping categories, Group Mapping and Participatory Mapping, because methods that involve individuals in the generation of a collective representation can yield very different outcomes from methods that involve a group.

\section{Evaluation criteria}

To improve the capacity of ES frameworks to address wicked problems, a participatory process should engage stakeholders in an interactive and iterative process of information sharing and negotiations (after Tippett et al. 2007, Voinov and Bousquet 2010), while also integrating social values into ES frameworks and developing four important elements of social capital: social learning and social capacity; transparency; the mediation of power; and trust.

Social values must be considered when establishing ES frameworks because these values are connected to current or aspirational activities and can be translated into practices that impact ecosystem function. Culture, history, identity, and subsequently, values, are all intimately connected with the biophysical environment, and are therefore not only associated with social, but also spatial, relationships (Stephenson 2008). Considering the range of values associated with a given area, and their spatial representation and interactions, can help to avoid an irreversible break in this social-ecological connection (Stephenson 2008). Trade-offs among values should be considered prior to making management or governance changes that will impact both social and biophysical space (Brown and Reed 2012). However, Chan et al. (2012) caution against treating all values equally because some cannot reasonably be traded or measured against other values. PM types that scored highly in the integration of social values category (Fig. 1) aim to establish a process that encourages diverse participation, including opportunities for multiple agents to be represented, and emphasizes equal participation from all stakeholders. PM types that received a low score in this category did not include processes that encouraged diversity, considered representation, or managed participation.

Social learning is a process that changes individual thinking and the thinking of the wider social group or community of practice through social interactions (Reed et al. 2010), and social capacity is the ability of a social group, network, or community to respond to feedback due to processes that generate and retain learning, meaning, knowledge, and experience and foster resilience in a social-ecological system (Folke et al. 2003, 2005). The ability to communicate, learn, and respond to feedback regarding the system in question as a social group is a critical element of any ES approach that intends to improve a wicked world (Granek et al. 2010). The ability of social learning and capacity building to develop shared understanding and agreement on which actions can be based is dependent on many factors, however, and should not be taken for granted (Muro and Jeffrey 2008). PM methods that achieved high scores in this category (Fig. 1) encourage social engagement and networking and require information sharing among participants, and the careful consideration of the perspectives of others. Generally, these approaches require face- 
Table 1. Types of participatory modeling that could be utilized in the development, implementation, and improvement of ecosystem services frameworks which aim to address wicked problems.

\begin{tabular}{|c|c|c|}
\hline $\begin{array}{l}\text { Type of Participatory } \\
\text { Modeling }\end{array}$ & Description & Sources \\
\hline Mediated Modeling (MM) & $\begin{array}{l}\text { MM requires intensive participation and commitment; stakeholders must work } \\
\text { collectively to develop a dynamic model through the conceptualization, specification, } \\
\text { and synthesis stages. Similar to GMB but with a focus on environmental applications. }\end{array}$ & $\begin{array}{l}\text { (Van Den Belt 2004, } \\
\text { Voinov and Bousquet } \\
\text { 2010, Videira et al. 2011) }\end{array}$ \\
\hline Group Mapping & $\begin{array}{l}\text { Group mapping is the process of representing spatial relationships among real-world } \\
\text { structures or objects undertaken by a group of people who are physically present for } \\
\text { the development of a collective representation. }\end{array}$ & (Kalibo and Medley 2007) \\
\hline Mental/Conceptual Modeling & $\begin{array}{l}\text { A simplified representation of reality that enables people to interact with the world; } \\
\text { functional rather than complete or accurate because of cognitive limitations. Shared } \\
\text { mental models of systems can be developed to support collective decision making. }\end{array}$ & $\begin{array}{l}\text { (Etienne et al. 2011, Jones } \\
\text { et al. 2011) }\end{array}$ \\
\hline Scenario Planning & $\begin{array}{l}\text { Scenarios aim to encourage learning about the future/anticipating the unexpected. } \\
\text { Useful when uncertainty and complexity are high. Involve developing likely } \\
\text { trajectories of important trends, but can also involve developing desired futures/ } \\
\text { actions needed to achieve them, or be adapted to indicate anticipated pathways and } \\
\text { identify key points of influence. }\end{array}$ & $\begin{array}{l}\text { (Peterson et al. 2003, } \\
\text { Lynam et al. 2007) }\end{array}$ \\
\hline $\begin{array}{l}\text { Group Model Building } \\
\text { (GMB) }\end{array}$ & $\begin{array}{l}\text { GMB involves a group of stakeholders in building a conceptual model with a } \\
\text { facilitator. Modeling is a process of building mutual understanding, defining terms, } \\
\text { and sharing ideas and experiences to make key strategic decisions. }\end{array}$ & $\begin{array}{l}\text { (Andersen et al. 2007, } \\
\text { Voinov and Bousquet } \\
\text { 2010) }\end{array}$ \\
\hline Companion Modeling (CM) & $\begin{array}{l}\text { CM usually involves a combination of agent-based models and role-playing games. } \\
\text { The model is constructed with stakeholders; the process aims to be transparent and } \\
\text { adaptive. Raising the awareness of stakeholders, including scientists, is a central } \\
\text { objective. Social learning, technical, or organizational innovation are expected } \\
\text { outcomes. }\end{array}$ & $\begin{array}{l}\text { (Souchère et al. 2010, } \\
\text { Voinov and Bousquet } \\
\text { 2010) }\end{array}$ \\
\hline Scoring & $\begin{array}{l}\text { Participants distribute counters onto cards, pictures, or other representations of } \\
\text { something of value according to the quantitative relationships/values that they } \\
\text { associate with it. Clarifies understandings and priorities. }\end{array}$ & $\begin{array}{l}\text { (Sheil and Liswanti 2006, } \\
\text { Lynam et al. 2007) }\end{array}$ \\
\hline Participatory Mapping & $\begin{array}{l}\text { Participatory mapping is the process of representing spatial relationships among real- } \\
\text { world structures or objects undertaken by individuals with the goal of contributing to } \\
\text { a collective representation. }\end{array}$ & $\begin{array}{l}\text { (Raymond et al. 2009, } \\
\text { Bryan et al. 2010, Klain } \\
\text { and Chan 2012) }\end{array}$ \\
\hline $\begin{array}{l}\text { Bayesian Belief Networks } \\
\text { (BBNs) }\end{array}$ & $\begin{array}{l}\text { BBNs are generally computer software packages that facilitate graphical } \\
\text { representation of a question or problem using a set of variables and their joint } \\
\text { probability distribution. Capable of utilizing qualitative and quantitative variables, } \\
\text { but struggles to handle feedback and represent temporal dynamics. }\end{array}$ & $\begin{array}{l}\text { (Cain 2001, Lynam et al. } \\
\text { 2007, Voinov and } \\
\text { Bousquet 2010) }\end{array}$ \\
\hline $\begin{array}{l}\text { System Dynamic Modeling } \\
\text { (SDM) }\end{array}$ & $\begin{array}{l}\text { SDM tools are generally computer software packages that facilitate the development } \\
\text { of representations of a problem or question in what is usually a numerical form. }\end{array}$ & (Lynam et al. 2007) \\
\hline Participatory Simulation (PS) & $\begin{array}{l}\text { Models and simulation games that involve system dynamics. HubNet enables internet } \\
\text { users to chat, control the behavior of individual objects or agents, and view } \\
\text { aggregated results. However, the settings and rules of the games cannot be modified } \\
\text { by participants. }\end{array}$ & $\begin{array}{l}\text { (Voinov and Bousquet } \\
\text { 2010, Netlogo } \underline{\text { htp:///ccl. }} \\
\text { northwestern.edu/netlogo/) }\end{array}$ \\
\hline
\end{tabular}

to-face contact among a participant group. PM methods that received a low score do not require lengthy social contact or the consideration of the values of others.

Transparency is critical to enabling communication among a diverse group of participants and decision makers. A lack of transparency can constitute one of the major factors responsible for failures in communication (McNie 2007) and, therefore, must be considered when aiming to resolve wicked problems. The transparency of a modeling process and the resulting model is intimately linked to the trust that stakeholders place in the PM process and its outputs (Korfmacher 2001), and therefore ways to increase transparency should be considered with care, especially if trust building is a project goal. Documentation, explanation of assumptions, and inspection of components are all techniques that can be used to design for transparency (Fleischmann and Wallace 2005). PM types with high transparency scores (Fig. 1) are generally simple, user-friendly, and flexible. Low scores are associated with the need for technical understanding or expertise to develop, undertake, and understand a specific PM method.

Power is conceived within this paper as being derived from the relations and practices of individuals and groups that produce particular outcomes, favoring some over others (Allen 2003, Castree and MacMillan 2001, Latour 2005). This relational or "network power" does not have to be wielded or exchanged through traditional power struggles, but "can be catalyzed by the mutual benefits vested in effective collaboration" (Juntti et al. 2009:211). Mutually beneficial power exchanges can be encouraged by participatory processes that engage a host of relevant stakeholders and decision makers. However, because power is derived from social relations, and PM is a social process, power mediation should be considered from the inception of a project to address inequalities that may diminish the capacity of participants to meaningfully engage (Reed 2008), to avoid 
engaging only the "usual suspects" (Stringer et al. 2006), and to avoid reinforcing or reproducing existing social structures (Hayward et al. 2004). Establishing fair and equal processes can enable collaboration and the redistribution of power (Shucksmith 2000), but applying participatory approaches in contexts that are characterized by social tensions and power differentials must be carefully considered because of the potential implications for less powerful actors (Becu et al. 2008). Where stakeholders feel their interests cannot be adequately represented, withholding participation may be a good strategy (Hayward et al. 2004). Types of PM with high scores (Fig. 1) encourage interactions among and between participants, organizers, and moderators, and rely on a mediation technique to negotiate power relations. The inclusion of a moderator in the process is a common way to address problems of power, but this is far from infallible (Reed 2008). Types of PM with low scores aim to gather information from participants for use in a model, but do not include a mechanism for facilitating interactions among and between participants, organizers, and moderators because creating a dialogue is not the intention.

Building trust has consistently been identified as necessary to the establishment of management and governance approaches that address wicked problems (Lebel et al. 2006), primarily because "trust lubricates collaboration" (Olsson et al. 2004:83). As Carolan succinctly explains, "we often find truth in those social relations we trust" (2006:327). PM can address both of these elements by establishing a process through which participants develop relationships, thereby building trust and creating the conditions for collaboration that are needed to facilitate improved outcomes for all parties. A process that builds trust is likely to result in high levels of information sharing and tightly knit social networks (Olsson et al. 2006). Enabling the linkages among different networks arguably makes it easier to avoid customary response paths and facilitate flexible or even novel solutions to management problems (Tompkins and Adger 2004). Conversely, highly polarized communities can become locked into undesirable management paths because of pre-existing conflict and mistrust among decision makers (Olsson et al. 2006). For this reason, successful comanagement invariably involves long periods of trust building (Pretty and Ward 2001, Olsson et al. 2004). Many different facets of trust could be considered when aiming to improve ES frameworks. For example, is the emphasis on building trust in the PM process itself, in the model resulting from the process, in the modelers or other experts, or among the participants? Each of these elements of trust were considered in the scoring shown in Figure 1, but high scores are associated with approaches that develop trust in the PM process itself, which we considered necessary for any further trust building to occur. Low scores are associated with processes that do not include any trustbuilding elements, and therefore assume that all participants will co-operate with the process no matter how it is conducted.

\section{Evaluation process}

Discourse-based valuation allows small groups to engage in a deliberative process resulting in consensus-based judgements about the values or orderings associated with multiple entities (Lynam et al. 2007). The ordering can use continuous, discrete, or nominal scales, depending on the metric utilized. Because of the lack of established quantitative scales and the inclusion of different variables in our evaluation criteria we used a nominal or rank-order scale to facilitate comparisons between PM types. We scored PM types on a 10-point scale and then normalized to 0 $1(0=$ Low, $1=$ High $)$, and applied equal weighting across the ranking criteria (Fig. 1). PM types were organized in Figure 1 from the highest total score (top) to the lowest total score (bottom). The resulting patterns can be read as illustrative of the capacity of different PM types. These results would not be replicated exactly by another group because of contextual differences in experience, but we would expect similar patterns to emerge if the same evaluation criteria were applied to other areas that grapple with wicked problems.

\section{RESULTS AND DISCUSSION}

\section{Integrating social values}

The integration of social values into ES frameworks can be achieved by establishing a process that emphasizes participation from a diverse group of stakeholders, including opportunities for nonhuman actors to be represented. Representation is a central concern for the integration of social values because questions of validity can arise if important stakeholders are not included, or if participants are not perceived to be representing the values of the area (see Reed 2008, Lane et al. 2011, and Krueger et al. 2012 for more).

Several types of PM scored highly in this category, with mediated modeling, scoring, and companion modeling scoring slightly higher than other PM types. Mediated modeling (Van Den Belt 2004) provides an initial facilitated brainstorming process that aims to expose a wide range of social values and concerns that are then integrated into a comprehensive problem statement developed and agreed upon by the participants. This is an effective but time-consuming process, and it can struggle with issues of stakeholder representation because of the extensive time commitment required, the strong emphasis on collaboration, and the technical and confusing language periodically utilized in workshops (Van Den Belt 2004). Companion modeling (Voinov and Bousquet 2010) is similarly time consuming but does not usually face the same problems with representation or commitment because it utilizes a combination of agent-based modeling and role-playing games to address resource management challenges, and these less personal approaches may be less threatening to participants than more explicitly collaborative processes. Because companion models are usually developed, at least in part, by modelers in advance of workshops, however, they are unlikely to be as stakeholder-driven as mediated modeling processes, and therefore risk missing the integration of important social values into the approach. Scoring processes (Sheil and Liswanti 2006), meanwhile, require very little time or prior knowledge about an SES to run, and are unlikely to be highly controversial because they do not require extensive collaboration on the topic of social values. They do, however, require participants to listen respectfully to one another's opinions. Scoring can integrate a wide range of social values, but because of the relatively short timeframes required it is less likely to generate the kind of long term outcomes that might be expected to arise from mediated modeling or companion modeling processes.

These three PM methods provide very different ways to integrate social values into ES frameworks, but they all require careful 
examination of a diverse set of social values within a specific context, which can help to reduce uncertainty and illuminate common goals as well as trade-offs. Many of the other PM methods evaluated also scored well in this category, indicating that there are a wide range of PM options for integrating social values into ES frameworks. A process that explores both what is valued and how those values and associated practices impact other stakeholders, including the ecosystem (Cote and Nightingale 2012), can make important contributions to the development of ES frameworks by providing context that may enable coordination, cooperation, and compromise.

\section{Enhancing social learning and capacity building}

Mental/conceptual modeling scored highest in the enhancing social learning and capacity building category, followed by mediated modeling (Fig. 1). Mental/conceptual modeling has been shown to support social learning (Pahl-Wostl and Hare 2004) and to enhance the collective decision making that builds capacity to address wicked problems (Lynam et al. 2002). Where mental/ conceptual modeling is undertaken as a PM initiative, it requires participants to develop a shared mental model of a system that is explicit about details such as key actors, resources, processes, and the interactions between and among these elements in a focal system (Etienne et al. 2011). The level of social interaction required to develop this kind of model is extensive, as is the detail that can emerge from such a process. However, mental/conceptual model elicitation practices are subject to ongoing research and therefore the approach may encounter some methodological challenges (Jones et al. 2011). Mediated modeling has been similarly touted for its ability to generate high levels of social learning and capacity building (Van Den Belt 2004), but requires stakeholders to be open to a more complex modeling process than is needed for stakeholder engagement in mental/conceptual modeling processes.

Scenario planning, group modeling building, and companion modeling share similar scores, whereas group mapping scored slightly lower. These PM methods each encourage social engagement and require information sharing among participants, but group mapping can be undertaken without extensive social interaction occurring if participants choose to avoid it. There is a notable split between the capacity of these first six PM methods, and the last five (scoring, Bayesian belief networks, system dynamic modeling, participatory simulation, and participatory mapping), to enhance social learning and build capacity within the participant group. This distinction is due to the social aspects of the first six methods, which all require extended face-to-face contact and demand that participants consider the perspectives of others through the modeling process. The bottom five methods do not require lengthy social contact or the consideration of the values of others.

Improving ES frameworks to resolve wicked problems necessitates that stakeholders learn about the problems at hand, specifically ecosystem function and the role that underpinning services play in service delivery, so that the trade-offs associated with decision making will be more clearly comprehended and better decisions can be made. This learning can coincide with the development of communication and negotiation skills that are needed to address wicked problems (Turnpenny et al. 2009). PM processes focused on enhancing social learning and capacity building may also be more likely to capture or generate the informal processes that contribute to knowledge generation and the networks that support adaptive governance and management (Cook and Spray 2012). The results of this study indicate that there are several PM methods that have a high capacity to create situations where stakeholders have to share knowledge to answer a question or resolve a problem (Pahl-Wostl and Hare 2004), and several that do not. This suggests that if social learning and capacity building are priorities, PM methods should be chosen with care, as some methods will encourage the generation of these qualities more readily than others.

\section{Increasing transparency}

All three of the PM methods that scored highest in the transparency category in Figure 1 are relatively simple processes that require little to no technical experience on the part of the participants. Participatory mapping, group mapping, and scoring all received high marks for transparency because of their userfriendliness, openness, and flexibility (Korfmacher 2001). The PM methods that scored lowest in the transparency category were participatory simulation, system dynamic modeling, Bayesian belief networks, and companion modeling, all of which require technical expertise to develop and undertake, and a high level of technical literacy for participants to comprehend.

The transparency of a modeling process and the resulting model is intimately linked to the trust that stakeholders place in the PM process and its outputs (Korfmacher 2001). However, it is possible to have a high level of transparency and yet build little trust, as illustrated by the participatory mapping category, which scored among the highest in the transparency category, but because it is not undertaken as part of a group, could not possibly build trust as effectively as methods that require group participation, such as group mapping.

These results clearly indicate that the PM methods associated with the highest levels of transparency are the simplest methods; those that do not require extensive technical expertise or time commitments on the part of participants. This finding is important to consider when developing ES frameworks because it is tempting to choose more complex PM processes that produce more detailed results, under the assumption that these will contribute to better outcomes. However, a transparent PM process is more likely to produce outputs that are supported by participants and the wider community, because the process builds trust in output validity and reasonableness (Yearley 2006), while also developing trust among participants (Granek et al. 2010). In some cases, model transparency might be exchanged for more detailed model outputs, but if stakeholders and decision makers do not trust a complicated model, they may be less likely to utilize its information (Primmer and Furman 2012), so this choice must be undertaken with care and, ideally, consultation. In most participatory situations, a simple model that can be communicated clearly is more useful than a complex model that lacks transparency, has narrow applications, high data costs, and more uncertainty (Brown Gaddis et al. 2010).

\section{Mediating power}

Scenario planning scored the highest in the power mediation category in Figure 1 because this type of PM encourages facilitated interactions among organizers, participants, and moderators. However, where invented futures are all that is at 
stake, the management of power and expectations is likely to be slightly easier than in other kinds of PM that are associated with real outcomes. Although scenario planning scored the highest of all the PM methods considered in this study, and several other PM methods provided some framework for power mediation, none of the PM methods yielded particularly promising results in terms of their capacity to mediate power. Similar to the distinct divisions in the enhancing social learning and capacity building category, PM methods are sharply divided in Figure 1 between those that provide some form of power mediation and those that do not, suggesting that extra care should be taken in the choice of PM methods if power issues among participants are anticipated to be a concern.

The lack of well-structured power mediation processes in many PM methods is a problem that should be considered carefully when designing any participatory approach. This raises particular concerns for the application of PM methods in the context of improving ES frameworks, because where this approach is of interest, there are likely to be high levels of conflict and preexisting power imbalances. These can be maintained or even exacerbated by processes that do not carefully consider how power will be mediated among participants, organizers, and any others involved in the process. Providing a voice to all participants increases the likelihood that the PM process will be perceived as fair and valid (Tippett et al. 2007), and will provide opportunities to review existing power structures and enhance social learning (Stringer et al. 2006). The ways in which the participant group mediates the boundaries among themselves and their respective outside interests and identities is a key component of how successful a participatory project may be perceived to be (PahlWostl et al. 2007).

\section{Building trust}

Mediated modeling scored highest in the trust building category, followed closely by group mapping and group model building. Trust in these three PM processes and their resulting models is fostered by including stakeholders in model development. This approach generally requires a simple, elegant model interface that allows a diverse group of stakeholders to clearly comprehend the structure of the model and all of its associated variables (Korfmacher 2001). Increasing stakeholder comprehension of the modeling process and input into model development can lead to improved model outputs as well as increased stakeholder trust in those outputs (Yearley 2006). Trust among participants and researchers can be developed by outlining clear goals and expected outcomes, and by involving stakeholders throughout all stages of a project, including defining process outcomes, thus creating a safe space for communication (Reed 2008). The opportunity to improve the welfare of all parties involved is also a critical element of trust building (Ostrom and Ahn 2009), and therefore managing participant expectations in relation to outcomes should be considered before beginning a study that intends to build trust (Lane et al. 2011). For example, the use or anticipated use of research findings in ways inconsistent with participant hopes can cause a breach of trust. The role of particular kinds of outcomes in the process of trust building is not clear from the literature; whether more trust is generated when working with high stakes or low stakes outcomes needs to be explored further (Kolkman et al. 2005).
This study indicates that the more involved a group of participants is in the process of modeling, the more they will trust the model outputs, and each other. Similar to the transparency results, this finding has important implications for the improvement of ES frameworks because it suggests that although complex models may seem preferable in some respects, if a model is to be believed and utilized, it is best to include stakeholders in its development.

\section{CONCLUSIONS}

Attempts to address the wicked problems of the 21st century must account for the interactional nature of ecological and social processes. Ecosystem service frameworks provide a link between the social and the ecological, but have largely failed to consider the critical role that social dynamics play in generating outcomes. Participatory modeling can improve ES frameworks by integrating social values and generating four critical elements of social capital: enhancing social learning and capacity building, increasing transparency, mediating power, and building trust. These qualities are needed to generate outcomes such as communicating, learning, and responding to feedback regarding the system in question as a social group, factors that can contribute to policy enactment and management changes that enhance the common good. To our knowledge, this is the first paper that has considered a range of PM processes in conjunction with the agency of their attributes.

Our findings, summarized in Figure 1, indicate that mediated modeling, group mapping, and mental/conceptual modeling have a high likelihood of generating a range of characteristics that encourage the establishment or improvement of ES frameworks, while participatory simulation, system dynamic modeling, and Bayesian belief networks have a low likelihood of generating these characteristics if utilized in isolation. Scoring, scenario planning, companion modeling, group model building, and participatory mapping all generate a moderate to high level of characteristics that improve the capacity of ES frameworks to address wicked problems. However, different PM types produce varying degrees of each characteristic, so project and participant needs and goals must be carefully considered when choosing PM methods. None of the types of PM considered in this paper are ideal for all situations; each is to some degree context dependent. Additionally, many of the qualities discussed here are interrelated and therefore benefits, or problems, in one area may affect other aspects of the process. In most participatory situations, however, a simple model that can be communicated clearly is more useful than a complex model associated with greater uncertainty. These challenges can only be met through active and ongoing experimentation in the very real, and very wicked, world.

\section{Responses to this article can be read online at: http://www.ecologyandsociety.org/issues/responses. $\mathrm{php} / 7581$}

\section{Acknowledgments:}

We would like to thank all those who participated in and assisted with the Manukau Harbour Ecosystem Services Workshops held in 2012, and the National Institute of Water and Atmospheric 
Research (NIWA) under Coasts and Oceans Research Programme 3 for providing funding for this research.

\section{LITERATURE CITED}

Adger, W. N. 1997. Sustainability and social resilience in coastal resource use. CSERGE Working Paper GEC 97-23. The Centre for Social and Economic Research on the Global Environment, School of Environmental Sciences, University of East Anglia, Norwich, UK. [online] URL: http://www.cserge.ac.uk/publications/ cserge-working-paper/gec-1997-23-sustainability-and-social-resiliencecoastal-resource-

Adger, W. N. 2003. Social capital, collective action, and adaptation to climate change. Economic Geography 79:387-404. http://dx.doi.org/10.1111/j.1944-8287.2003.tb00220.x

Allen, J. 2003. Lost geographies of power. Blackwell, Oxford, UK. http://dx.doi.org/10.1002/9780470773321

Andersen, D. F., J. A. M. Vennix, G. P. Richardson, and E. A. J. A. Rouwette. 2007. Group model building: problem structing, policy simulation and decision support. Journal of the Operational Research Society 58(5):691-694. http://dx.doi.org/10.1057/ palgrave.jors. 2602339

Arnstein, S. R. 1969. A ladder of citizen participation. Journal of the American Institute of Planners 35:216-224. http://dx.doi. org/10.1080/01944366908977225

Becu, N., A. Neef, P. Schreinemachers, and C. Sangkapitux. 2008. Participatory computer simulation to support collective decisionmaking: potential and limits of stakeholder involvement. Land Use Policy 25:498-509. http://dx.doi.org/10.1016/j.landusepol.2007.11.002

Beierle, T. C., and J. Cayford. 2002. Democracy in practice: public participation in environmental decisions. Resources for the Future, Washington, D.C., USA.

Berkes, F., J. Colding, and C. Folke. 2003. Introduction. Pages 1-30 in F. Berkes, J. Colding, and C. Folke, editors. Navigating social-ecological systems: building resilience for complexity and change. Cambridge University Press, Cambridge, UK. http://dx. doi.org/10.1017/cbo9780511541957.003

Berkes, F., and C. S. Seixas. 2005. Building resilience in lagoon social-ecological systems: a local-level perspective. Ecosystems 8:967-974. http://dx.doi.org/10.1007/s10021-005-0140-4

Brown, G. G., and P. Reed. 2012. Social landscape metrics: measures of understanding place values from Public Participation Geographic Information Systems (PPGIS). Landscape Research 37(1):73-90. http://dx.doi.org/10.1080/01426397.2011.591487

Brown Gaddis, E. J., H. Harp Falk, C. Ginger, and A. Voinov. 2010. Effectiveness of a participatory modeling effort to identify and advance community water resource goals in St. Albans, Vermont. Environmental Modelling \& Software 25(11):1428-1438. http://dx.doi.org/10.1016/j.envsoft.2009.06.004

Brown, V. A., P. M. Deane, J. A. Harris and J. Y. Russell. 2010. Towards a just and sustainable future. Pages 3-15 in V. A. Brown, J. A. Harris, and J. Y. Russell, editors. Tackling wicked problems: through the transdisciplinary imagination. Earthscan, London, UK.
Bryan, B. A., C. M. Raymond, N. D. Crossman, and D. Hatton MacDonald. 2010. Targeting the management of ecosystem services based on social values: where, what, and how? Landscape and Urban Planning 97:111-122. http://dx.doi.org/10.1016/j. landurbplan.2010.05.002

Cain, J. 2001. Planning improvements in natural resource management: guidelines for using Bayesian networks to support the planning and management of development programmes in the water sector and beyond. Centre for Ecology \& Hydrology, Wallingford, UK. [online] URL: http://nora.nerc.ac.uk/9461/

Carolan, M. S. 2006. Social change and the adoption and adaptation of knowledge claims: whose truth do you trust in regard to sustainable agriculture? Agriculture and Human Values 23:325-339. http://dx.doi.org/10.1007/s10460-006-9006-4

Castree, N., and T. MacMillan. 2001. Dissolving dualisms: actor networks and the reimagination of nature. Pages 208-224 in N. Castree and B. Braun, editors. Social nature: theory, practice and politics. Blackwell, Oxford, UK.

Chan, K. M. A., T. Satterfield, and J. Goldstein. 2012. Rethinking ecosystem services to better address and navigate cultural values. Ecological Economics 74:8-18. $\quad$ http://dx.doi.org/10.1016/j. ecolecon.2011.11.011

Cook, B. R., and C. J. Spray. 2012. Ecosystem services and integrated water resource management: different paths to the same end? Journal of Environmental Management 109:93-100. http://dx.doi.org/10.1016/j.jenvman.2012.05.016

Cote, M., and A. J. Nightingale. 2012. Resilience thinking meets social theory: situating social change in socio-ecological systems (SES) research. Progress in Human Geography 36(4):475-489. http://dx.doi.org/10.1177/0309132511425708

Daniel, T. C., A. Muhar, A. Arnberger, O. Aznar, J. W. Boydd, K. M. A. Chan, R. Costanza, T. Elmqvist, C. G. Flint, P. H. Gobster, A. Grêt-Regamey, R. Lave, S. Muhar, M. Penker, R. G. Ribe, T. Schauppenlehner, T. Sikor, I. Soloviy, M. Spierenburg, K. Taczanowska, J. Tam, and A. von der Dunk. 2012. Contributions of cultural services to the ecosystem services agenda. Proceedings of the National Academy of Sciences 109(23):8812-8819.

Etienne, M., D. R. Du Toit and S. Pollard. 2011. ARDI: a coconstruction method for participatory modeling in natural resources management. Ecology and Society 16(1): 44. [online] URL: http://www.ecologyandsociety.org/vol16/iss1/art44/

Fleischmann, K. R., and W. A. Wallace. 2005. A covenant with transparency: opening the black box of models. Communications of the ACM 48(5):93-97. http://dx.doi.org/10.1145/1060710.1060715

Folke, C., J. Colding, and F. Berkes. 2003. Synthesis: building resilience and adaptive capacity in social-ecological systems. Pages 352-387 in F. Berkes, J. Colding, and C. Folke, editors. Navigating social-ecological systems: building resilience for complexity and change. Cambridge University Press, Cambridge, UK. http://dx.doi.org/10.1017/cbo9780511541957.020

Folke, C., T. Hahn, P. Olsson, and J. Norberg. 2005. Adaptive governance of social-ecological systems. Annual Review of Environment and Resources 30:441-473. http://dx.doi.org/10.1146/ annurev.energy.30.050504.144511 
Gadgil, M., P. Olsson, F. Berkes, and C. Folke. 2003. Exploring the role of local ecological knowledge in ecosystem management: three case studies. Pages 189-209 in F. Berkes, J. Colding, and C. Folke, editors. Navigating social-ecological systems: building resilience for complexity and change. Cambridge University Press, Cambridge, UK. http://dx.doi.org/10.1017/cbo9780511541957.013

Granek, E. F., S. Polasky, C. V. Kappel, D. J. Reed, D. M. Stoms, E. W. Koch, C. J. Kennedy, L. A. Cramer, S. D. Hacker, E. B. Barbier, S. Aswani, M. Ruckelshaus, G. M. E. Perillo, B. R. Silliman, N. Muthiga, D. Bael, and E. Wolanski. 2010. Ecosystem services as a common language for coastal ecosystem-based management. Conservation Biology 24(1):207-216. http://dx.doi. org/10.1111/j.1523-1739.2009.01355.X

Haag, D., and M. Kaupenjohann. 2001. Parameters, prediction, post-normal science and the precautionary principle - a roadmap for modelling for decision-making. Ecological Modelling 144:45-60. http://dx.doi.org/10.1016/S0304-3800(01)00361-1

Hayward, C., L. Simpson, and L. Wood. 2004. Still left out in the cold: problematising participatory research and development. Sociologia Ruralis 44(1):95-108. http://dx.doi.org/10.1111/ j.1467-9523.2004.00264.x

Irvin, R. A., and J. Stansbury. 2004. Citizen participation in decision making: is it worth the effort? Public Administration Review 64(1):55-65. http://dx.doi.org/10.1111/j.1540-6210.2004.00346. $\underline{\mathrm{x}}$

Jones, N. A., H. Ross, T. Lynam, P. Perez, and A. Leitch. 2011. Mental models: an interdisciplinary synthesis of theory and methods. Ecology and Society 16(1): 46. [online] URL: http:// www.ecologyandsociety.org/vol16/iss1/art46/

Juntti, M., D. Russel, and J. Turnpenny. 2009. Evidence, politics and power in public policy for the environment. Environmental Science \& Policy 12:207-215. http://dx.doi.org/10.1016/j. envsci.2008.12.007

Kalibo, H. W., and K. E. Medley. 2007. Participatory resource mapping for adaptive collaborative management at Mt. Kasigau, Kenya. Landscape and Urban Planning 82:145-158. http://dx.doi. org/10.1016/j.landurbplan.2007.02.005

Klain, S. C., and K. M. A. Chan. 2012. Navigating coastal values: participatory mapping of ecosystem services for spatial planning. Ecological Economics 82:104-113. http://dx.doi.org/10.1016/j. ecolecon.2012.07.008

Kolkman, M. J., M. Kok, and A. van der Veen. 2005. Mental model mapping as a new tool to analyse the use of information in decision-making in integrated water management. Physics and Chemistry of the Earth 30:317-332. http://dx.doi.org/10.1016/j. pce.2005.01.002

Korfmacher, K. S. 2001. The politics of participation in watershed modeling. Environmental Management 27(2):161-176. http://dx. doi.org/10.1007/s002670010141

Krueger, T., T. Page, K. Hubacek, L. Smith, and K. Hiscock. 2012. The role of expert opinion in environmental modelling. Environmental Modelling \& Software 36:4-18. http://dx.doi. org/10.1016/i.envsoft.2012.01.011
Lane, S. N., N. Odoni, C. Landström, S. J. Whatmore, N. Ward, and S. Bradley. 2011. Doing flood risk science differently: an experiment in radical scientific method. Transactions of the Institute of British Geographers 36:15-36. http://dx.doi. org/10.1111/j.1475-5661.2010.00410.x

Latour, B. 2005. Politics of nature: how to bring the sciences into democracy. Harvard University Press, London, UK.

Lebel, L., J. M. Anderies, B. Campbell, C. Folke, S. HatfieldDodds, T. P. Hughes, and J. Wilson. 2006. Governance and the capacity to manage resilience in regional social-ecological systems. Ecology and Society 11(1): 19. [online] URL: http://www. ecologyandsociety.org/vol11/iss1/art19/

Lynam, T., F. Bousquet, C. Le Page, P. d'Aquino, O. Barreteau, F. Chinembiri, and B. Mombeshora. 2002. Adapting science to adaptive managers: Spidergrams, belief models, and multi-agent systems modeling. Conservation Ecology 5(2): 24. [online] URL: http://www.consecol.org/vol5/iss2/art24/ http://dx.doi. org/10.1079/9780851997315.0157

Lynam, T., W. de Jong, D. Sheil, T. Kusumanto, and K. Evans. 2007. A review of tools for incorporating community knowledge, preferences, and values into decision making in natural resources management. Ecology and Society 12(1): 5. [online] URL: http:// www.ecologyandsociety.org/vol12/iss1/art5/

McNie, E. C. 2007. Reconciling the supply of scientific information with user demands: an analysis of the problem and review of the literature. Environmental Science \& Policy 10:17-38. http://dx.doi.org/10.1016/j.envsci.2006.10.004

Millennium Ecosystem Assessment. 2003. Ecosystems and human well-being: a framework for assessment. Island Press, Washington, D.C., USA. [online] URL: http://www.unep.org/maweb/en/ Framework.aspx

Millennium Ecosystem Assessment. 2005. Ecosystems and human well-being: current state and trends assessment. Island Press, Washington, D.C., USA. [online] URL: http://www.unep.org/ maweb/en/Condition.aspx

Millington, J. D. A., D. Demeritt, and R. Romero-Calcerrada. 2011. Participatory evaluation of agent-based land-use models. Journal of Land Use Science 6:195-210. http://dx.doi. org/10.1080/1747423X.2011.558595

Morris, J. C., W. A. Gibson, W. M. Leavitt, and S. C. Jones. 2013. Restoring Princess Elizabeth's River. The case for grassroots collaboration: Social capital and ecosystem restoration at the local level. Lexington Books, Maryland, USA.

Muro, M., and P. Jeffrey. 2008. A critical review of the theory and application of social learning in participatory natural resource management processes. Journal of Environmental Planning and Management 51(3):325-344. http://dx.doi.org/10.1080/09640560$\underline{801977190}$

Nelkin, D., and M. Pollak. 1979. Public participation in technological decisions: reality or grand illusion? Technology Review 9:55-64.

Olsson, P., C. Folke, and F. Berkes. 2004. Adaptive comanagement for building resilience in social-ecological systems. Environmental Management 34(1):75-90. http://dx.doi.org/10.1007/s00267-003-0101-7 
Olsson, P., L. H. Gunderson, S. R. Carpenter, P. Ryan, L. Lebel, C. Folke, and C. S. Holling. 2006. Shooting the rapids: navigating transitions to adaptive governance of social-ecological systems. Ecology and Society 11(1): 18. [online] URL: http://www. ecologyandsociety.org/vol11/iss1/art18/

Ostrom, E., and T. K. Ahn. 2009. The meaning of social capital and its link to collective action. In G. T. Svendsen and G. L. Svendsen, editors. Handbook of social capital: the troika of sociology, political science, and economics. Edward Elgar, Cheltenham, UK. http://dx.doi.org/10.4337/9781848447486.00008

Pahl-Wostl, C., and M. Hare. 2004. Processes of social learning in integrated resources management. Journal of Community \& Applied Social Psychology 14:193-206. http://dx.doi.org/10.1002/ casp.774

Pahl-Wostl, C., J. Sendzimir, P. Jeffrey, J. Aerts, G. Berkamp, and K. Cross. 2007. Managing change toward adaptive water management through social learning. Ecology and Society 12(2): 30. [online] URL: http://www.ecologyandsociety.org/vol12/iss $2 /$ $\underline{\operatorname{art} 30 /}$

Peterson, G. D., G. S. Cumming, and S. R. Carpenter. 2003. Scenario planning: a tool for conservation in an uncertain world. Conservation Biology 17(2):358-366. http://dx.doi.org/10.1046/ j.1523-1739.2003.01491.x

Prell, C., K. Hubacek, M. Reed, C. Quinn, N. Jin, J. Holden, T. Burt, M. Kirby, and J. Sendzimir. 2007. If you have a hammer everything looks like a nail: traditional versus participatory model building. Interdisciplinary Science Reviews 32(3):263-282. http:// dx.doi.org/10.1179/030801807x211720

Pretty, J., and H. Ward. 2001. Social capital and the environment. World Development 29(2):209-227. http://dx.doi.org/10.1016/ s0305-750x(00)00098-X

Primmer, E., and M. Furman. 2012. Operationalising ecosystem service approaches for governance: do measuring, mapping and valuing integrate sector-specific knowledge systems? Ecosystem Services 1:85-92. [online] URL: http://dx.doi.org/10.1016/j. ecoser.2012.07.008

Raymond, C. M., B. A. Bryan, D. Hatton MacDonald, A. Cast, S. Strathearn, A. Grandgirard, and T. Kalivas. 2009. Mapping community values for natural capital and ecosystem services. Ecological Economics 68:1301-1315. http://dx.doi.org/10.1016/j. ecolecon.2008.12.006

Raymond, C. M., I. Fazey, M. S. Reed, L. C. Stringer, G. M. Robinson, and A. C. Evely. 2010. Integrating local and scientific knowledge for environmental management. Journal of Environmental Management 91:1766-1777. http://dx.doi.org/10.1016/ j.jenvman.2010.03.023

Reed, M. S. 2008. Stakeholder participation for environmental management: a literature review. Biological Conservation 141:2417-2431. http://dx.doi.org/10.1016/j.biocon.2008.07.014

Reed, M. S., A. C. Evely, G. Cundill, I. Fazey, J. Glass, A. Laing, J. Newig, B. Parrish, C. Prell, C. Raymond, and L. C. Stringer. 2010. What is social learning? Ecology and Society 15(4): r1. [online] URL: http://www.ecologyandsociety.org/vol15/iss4/ resp1/
Reyers, B., R. Biggs, G. S. Cumming, T. Elmqvist, A. P. Hejnowicz, and S. Polasky. 2013. Getting the measure of ecosystem services: a social-ecological approach. Frontiers in Ecology and the Environment 11:268-273. http://dx.doi.org/10.1890/120144

Rowe, G., and L. J. Frewer. 2000. Public participation methods: a framework for evaluation. Science, Technology, \& Human Values 25(1):3-29. http://dx.doi.org/10.1177/016224390002500101

Sheil, D., and N. Liswanti. 2006. Scoring the importance of tropical forest landscapes with local people: patterns and insights. Environmental Management 38(1):126-136. http://dx.doi.org/10.1007/ s00267-005-0092-7

Shucksmith, M. 2000. Endogenous development, social capital and social inclusion: perspectives from LEADER in the UK. Sociologia Ruralis 40(2):208-218. http://dx. doi.org/10.1111/1467-9523.00143

Souchère, V., L. Millair, J. Echeverria, F. Bousquet, C. Le Page, and M. Etienne. 2010. Co-constructing with stakeholders a roleplaying game to initiate collective management of erosive runoff risks at the watershed scale. Environmental Modelling \& Software 25:1359-1370. http://dx.doi.org/10.1016/j.envsoft.2009.03.002

Stephenson, J. 2008. The cultural values model: an integrated approach to values in landscapes. Landscape and Urban Planning 84:127-139. http://dx.doi.org/10.1016/j.landurbplan.2007.07.003

Stringer, L. C., A. J. Dougill, E. Fraser, K. Hubacek, C. Prell, and M. Reed. 2006. Unpacking "participation" in the adaptive management of social-ecological systems: a critical review. Ecology and Society 11(2): 39. [online] URL: http://www. ecologyandsociety.org/vol11/iss2/art39/

Tippett, J., J. F. Handley and J. R. Ravetz. 2007. Meeting the challenges of sustainable development-a conceptual appraisal of a new methodology for participatory ecological planning. Progress in Planning 67:9-98. http://dx.doi.org/10.1016/j. progress.2006.12.004

Tippett, J., B. Searle, C. Pahl Wostl, and Y. Rees. 2005. Social learning in public participation in river basin management-early findings from HarmoniCOP European case studies. Environmental Science \& Policy 8(3):287-299. http://dx.doi.org/10.1016/j. envsci.2005.03.003

Tompkins, E. L., and W. N. Adger. 2004. Does adaptive management of natural resources enhance resilience to climate change? Ecology and Society 9(2): 10. [online] URL: http://www. ecologyandsociety.org/vol9/iss2/art10/

Turnpenny, J. T., I. Lorenzoni, and M. Jones. 2009. Noisy and definitely not normal: responding to wicked issues in the environment, energy and health. Environmental Science \& Policy 12:347-358. http://dx.doi.org/10.1016/j.envsci.2009.01.004

Van den Belt, M. 2004. Mediated modeling: a system dynamics approach to environmental consensus building. Island Press, Washington, D.C., USA.

van Wyk, E., D. J. Roux, M. Drackner, and S. F. McCool. 2008. The impact of scientific information on ecosystem management: making sense of the contextual gap between information providers and decision makers. Environmental Management 41:779-791. http://dx.doi.org/10.1007/s00267-008-9084-8 
Videira, N., M. Van den Belt, P. Antunes, R. Santos, and R. Boumans. 2011. Integrated modeling of coastal and estuarine ecosystem services. Pages 79-108 in E. Wolanski, D. McLusky, M. Van den Belt, and R. Costanza, editors. Ecological economics of estuaries and coasts. Treatise on estuarine and coastal science, 12. Academic Press, London, UK. http://dx.doi.org/10.1016/ b978-0-12-374711-2.01205-5

Voinov, A., and F. Bousquet. 2010. Modelling with stakeholders. Environmental Modelling \& Software 25:1268-1281. http://dx.doi. org/10.1016/j.envsoft.2010.03.007

Weidemann, P. M., and S. Femers. 1993. Public-participation in waste management decision making: analysis and management of conflicts. Journal of Hazardous Materials 33(3):355-368.

Wilson, M. A., and R. B. Howarth. 2002. Discourse-based valuation of ecosystem services: establishing fair outcomes through group deliberation. Ecological Economics 41:431-443. http://dx.doi.org/10.1016/S0921-8009(02)00092-7

Yearley, S. 2006. Bridging the science-policy divide in urban airquality management: evaluating ways to make models more robust through public engagement. Environment and Planning $C$ : Government and Policy 24:701-714. http://dx.doi.org/10.1068/ c0610j 